(c) Науменко О.М., Мойсеєнко В.О., 2020 doi: 10.37321/nefrology.2020.26-27-08 УДК 616.61:061.3(477)

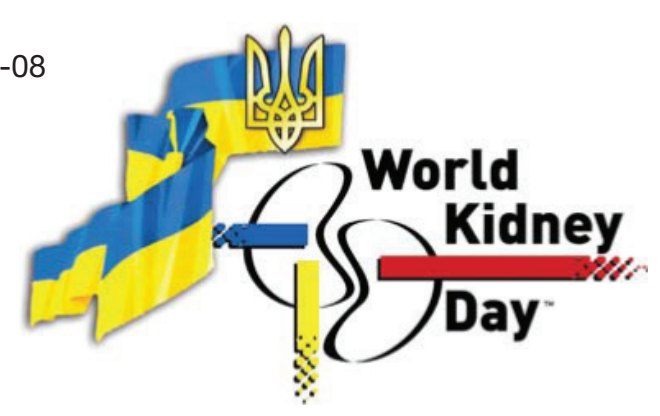

\title{
ЗДОРОВ'Я НИРОК ДЛЯ ВСІХ І СКРІЗЬ - ВІД ПРОФІЛАКТИКИ ДО ВИЯВЛЕННЯ ТА РІВНОПРАВНОГО ДОСТУПУ ДО ДОПОМОГИ
}

(за матеріалами наукових заходів, присвячених Всесвітньому Дню нирки - 2020, м. Київ)

\author{
НАУМЕНКО О.М., МОЙСЕЄНКО В.О. \\ Національний медичний університет імені О.О. Богомольця
}

Резюме.

Ключові слова:
Всесвітній день здоров'я (World Health Day) відзначається щорічно 7 квітня в день його створення в 1948 році Всесвітньою організацією охорони здоров'я (World Health Organization, WHO). За час, що минув з того історичного моменту, членами Всесвітньої організації охорони здоров'я (ВООЗ) стали 194 держави світу. Щорічне проведення Дня здоров'я стало традицією з 1950 року. Заходи Дня проводяться для того, щоб люди могли зрозуміти, як багато значить здоров'я в їхньому житті. А організації охорони здоров'я та лікарі покликані вирішити питання, що їм потрібно зробити, щоб здоров'я людей в усьому світі стало краще.

Цьогоріч в м. Києві у рамках Всесвітнього Дня нирки-2020 відбулися заходи з нагоди Всесвітнього Дня нирки «Здорові нирки: профілактика, рання діагностика, доступність спеціалізованої медичної допомоги» («Kidney Health for Everyone Everywhere - from Prevention to Detection and Equitable Access to Care»): під егідою ДУ «Інститут нефрології НАМН України», Української Асоціації нефрологів, Національного ниркового фонду, за ініціативи Національної медичної академії післядипломної освіти імені П.Л. Шупика - науково-практична конференція. На конференції були представлені доповіді про причини формування XXH: діабетичну і гіпертензивну нефропатію, іммунобіологічну терапію ритуксимабом, IgG4-асоційоване захворювання, морфологію IgG4-RD, XXH і цереброваскулярну протекцію.

Всесвітній День нирки, хронічна хвороба нирок, діагностика, лікування, нирково-замісна терапія.
Не дивлячись на складні життєві обставини, в умовах пандемії Covid-19, Україна дистанційно приєдналась до Світової глобальної ініціативи в структурі щорічного міжнародного проекту "World Kidney Day" - Всесвітній День нирки_2020: «Здорові нирки: профілактика, рання діагностика, доступність спеціалізованої медичної допомоги» («Kidney Health for Everyone Everywhere - from Prevention to Detection and Equitable Access to Care»).

Ініціатива проведення Всесвітнього Дня нирки покликана привернути увагу світової спільноти - пересічних громадян та професійних лікарів - до профілактики та обізнаності про хронічні хвороби нирок, знизити частоту захворюваності та покращення якості життя громадян через профілактику. Всесвітній День нирки відзначають в понад 100 країнах світу.

До заходів з нагоди Всесвітнього Дня нирки 2020 долучилися молоді науковці Національного медичного університету імені О.О. Богомольця. На практичних заняттях з нефрології як вітчизняні, так і іноземні студенти на занятті «Cardinal symptoms and signs of renal diseases. Genitourinary examination. Diagnostic tests in nephrology. Changes in the oral cavity in patients with renal diseases» дізналися багато цікавого з історії становлення Міжнародного Дня нирки та мали змогу 
розібрати практичні кейси з історіями хвороб пацієнтів з ураженнями нирок. Дистанційні заняття сприяли розширенню аудиторії слухачів та активній дискусії.

Під егідою ДУ «Інститут нефрології НАМН України», гО "Українська асоціація нефрологів і фахівців з трансплантації нирки”, Національного ниркового фонду під час заходів, присвячених Міжнародному Дню нирки-2020 розглянуті основні проблеми: розповсюдженість XXH у дорослих та дітей в Україні та у світі, фактори ризику уражень нирок: обізнаність населення та медичних працівників, профілактика, скринінг та лікування XXН у дорослих та дітей, роль медичних працівників в ранньому виявленні та зниженні розповсюдженості XXН в групах високого ризику, роль місцевих та Національних органів охорони здоров'я в боротьбі з епідемією XXН.

Були заплановані спеціалізовані майстер-класи з нефрології: зміна парадигми профілактики, діагностики та лікування контраст-індукованої нефропатії (проф. М.О. Колесник), оптимальні підходи до застосування залізомістких лікарських засобів в лікуванні анемії у хворих на XXН (к.мед.н. I.М. Шіфріс), лікування артеріальної гіпертензії на різних стадіях XXН (проф. І.О. Дудар).

За ініціативи Національної медичної академії післядипломної освіти імені П.Л. Шупика, кафедри нефрології та НЗТ НМАПО імені П.Л. Шупика і нефрологічної клініки проф. Д. Іванова пройшла дистанційна Науково-практична конференція 3 міжнародною участю «Актуальні питання нефрології, діалізу та трансплантації - Всесвітній день нирки 2020». Заслухані питання про причини формування XXH: діабетичну і гіпертензивну нефропатію, іммунобіологічну терапію ритуксимабом, lgG4-асоційоване захворювання, морфологію IgG4-RD, XXH і цереброваскулярну протекцію. Обмін досвідом відбувся на засіданні круглого столу «XXН та їі ризики» та під час майстер-класів «ннфекції сечової системи» (проф. Д.Д. Іванов) та «Васкуліти» (д.мед.н. Бевзенко Т.Б.).

Під час секційного засідання «Від ХХН до нирково-замісної терапії» розглянуті предиктори несприятливого результату у пацієнтів з IgA-нефропатією (к.мед.н. Комісарів К.С., ГУ «Мінський науково-практичний центр хірургії, трансплантації та гематології», М.В. Дмітрієва і Т.А. Летковська, УО «Білоруський державний медичний університет»), гідратація при XXH, діуретична терапія (проф. Іванов Д.Д.), особливості нирково-замісної терапії у літніх пацієнтів з хронічною хворобою нирок (к.мед.н. Комісарів К.С., ГУ «Мінський науково-практичний центр хірургії, трансплантації та гематології» і Курилович К.А., ДУО «Білоруська медична академія післядипломної освіти»), клінічна значимість маркеру гострого пошкодження нирок в прогнозуванні розвитку прееклампсії у вагітних (проф. В.Г. Марічереда В.Г., к.мед.н. Бер- лінська Л.І., Одеський національний медичний університет, кафедра акушерства та гінекології №1), ревматологічні захворювання з ураженням нирок у вагітних, розширений ГД, проведені майстер-класи УАДН/УАН: Гідратація і XXН, УАДН/ УАН: КІ-ГУН.

Під час роботи секції «Дитяча нефрологія» розглянуті надзвичайно важливі питання дитячої нефрології: сучасні знання про орфанні захворювання, СЧВ: морфологія і рітуксимаб, нирки і вегето-судинні дисфункції у дітей та підлітків, перехід ХЗН в XXН: діти-дорослі, відбулася демонстрація клінічних випадків. Проведені майстер-класи «Туберозний склероз (школа лікаря і пацієнта)», імуносупресія при туберозному комплексі, туберозний склероз (дискусія), УАДН/УАН: ІCС у жінок в періменопаузі, УАДН/УАН: АГ і ХХН.

Участь у конференції взяли лікарі зі спеціальностей «нефрологія», «кардіологія», «ендокринологія», «терапія», «сімейна медицина», «педіатрія», «дитяча нефрологія» та фахівці з трансплантації нирки, завідувачі кафедр та викладачі вищих медичних навчальних закладів III-IV рівнів акредитації та закладів післядипломної освіти, діяльність яких пов'язана з питаннями нефрології та дитячої нефрології.

Що ви можете зробити для своїх нирок?

Вісім Золотих Правил допоможуть знизити ризик розвитку захворювань нирок:

- Зберігайте хорошу фізичну форму

- Регулярно вимірюйте рівень цукру в крові

- Контролюйте свій артеріальний тиск

- ̈жте здорову їжу і стежте за вагою

- Підтримуйте здоровий баланс рідини

- Не паліть

- Не приймайте регулярно ліки, які продаються без рецепта

- При наявності одного або більше факторів ризику необхідно регулярно проводити обстеження нирок.

Таким чином, Україна традиційно приєдналася до заходів з нагоди Всесвітнього Дня нирки щоб об'єднати зусилля лікарів і пацієнтів щодо покращення діагностики і лікування хронічної хвороби нирок.

\section{SUMMARY}

\section{KIDNEY HEALTH FOR EVERYONE EVERYWHERE - FROM PREVENTION TO DETECTION AND EQUITABLE ACCESS TO CARE (TO THE WORLD KIDNEY DAY-2020)}

\author{
Naumenko O., Moyseyenko V. \\ (Kyiv)
}

World Health Day is celebrated on the day of the creation in 1948 of the World Health Organization (WHO). In the time that has passed since that historical moment, 194 states of the world have become members of the World Health Organization (WHO). The annual holding of the Day of Health has become a tradition since the 1950s. The 
events of the Day are held so that people can understand how much health means in their lives. And health organizations and doctors are called upon to decide what they need to do to improve the health of people around the world.

On 2020, a scientific-practical conference «Kidney Health for Everyone Everywhere - from Prevention to Detection and Equitable Access to Care» took place in Kyiv within the framework of the World Day of the Kidney 2020 the auspices of SI "Institute of Nephrology AMS of Ukraine," Ukrainian Association of Nephrology, National Kidney Foundation, the initiative of the Shupyk National Medical Academy of Postgraduate Education. The conference presented reports on kidney disease, mechanisms and factors of progression consider interdisciplinary aspects of modern nephrology, diagnosis and treatment. Workshops and discussion of interdisciplinary aspects of modern nephrology diagnosis and treatment took place.

Key words: World Kidney Day, chronic kidney disease, diagnosis, treatment, renal replacement therapy.

\section{PЕЗЮME}

\section{ЗДОРОВЫЕ ПОЧКИ: ПРОФИЛАКТИКА, РАННЯЯ ДИАГНОСТИКА, ДОСТУПНОСТЬ СПЕЦИАЛИЗИРОВАННОЙ МЕДИЦИНСКОЙ ПОМОщи}

(по материалам научно-практической конференции, приуроченной ко Всемирному Дню почки - 2020)

Науменко А.Н., Мойсеенко В.А.

Всемирный день здоровья отмечается в день создания в 1948 году Всемирной организации здравоохранения (ВОЗ). За время, прошедшее с того исторического момента, 194 государства мира стали членами Всемирной организации здравоохранения (ВОЗ). Ежегодное проведение Дня здоровья стало традицией с 1950-х годов. Мероприятия Дня проводятся для того, чтобы люди понимали, что значит здоровье в их жизни. А медицинские организации и врачи призваны решить, что им нужно делать для улучшения здоровья людей во всем мире.

В 2020 году в Киеве дистанционно состоялась научно-практическая конференция «Здоровые почки: профилактика, ранняя диагностика, доступность специализированной медицинской помощи» в рамках Всемирного дня почек-2020 под эгидой ГУ «Институт нефрологии АМН Украины», Украинской ассоциации нефрологов, Национального фонда почек, инициативы Национальной медицинской академии последипломного образования им. Шупика. На конференции были представлены доклады о заболеваниях почек, механизмах и факторах прогрессирования, рассмотрены междисциплинарные аспекты современной нефроло- гии, диагностики и лечения. Состоялись семинары и обсуждение междисциплинарных аспектов современной нефрологической диагностики и лечения.

Ключевые слова: Всемирный день почек, хроническая болезнь почек, диагностика, лечение, заместительная почечная терапия.

\section{АВТОРСЬКА ДОВІДКА}

Мойсеєнко Валентина Олексіївна Національний медичний університет імені О.О. Богомольця, д.м.н., професор моб.: +380677779249

E-mail: moyseyenko vo@ukr.net

Мойсеенко Валентина Алексеевна Национальный медицинский университет имени А.А. Богомольца, д.м.н., профессор моб .: +380677779249

E-mail: moyseyenko vo@ukr.net

\section{Moyseyenko Valentyna}

Bogomolets National Medical University, MD, Professor

mob .: +380677779249

E-mail: moyseyenko vo@ukr.net

\section{Науменко Олександр Миколайович}

Національний медичний університет імені О.О. Богомольця, перший проректор з науково-педагогічної роботи та післядипломної освіти, професор, д.мед.н. Тел.: 067-777-92-49

E-mail: lorcafedranmu@gmail.com

\section{Науменко Александр Николаевич}

Национальный медицинский университет имени А.А. Богомольца, первый проректор по научно-педагогической работе и последипломному образованию, профессор, д.мед.н. Тел.: 067-777-92-49 E-mail: lorcafedranmu@gmail.com

\section{Naumenko Oleksandr}

National Medical University named after O. Bogomolets, first vice-rector for scientific and pedagogical work and postgraduate education, professor, doctor of medical sciences

Tel.: 067-777-92-49

E-mail: lorcafedranmu@gmail.com 


\section{ІНФОРМАЦІЯ ДЛЯ АВТОРІВ (INFORMATION FOR AUTHORS ИНФОРМАЦИЯ ДЛЯ АВТОРОВ)}

Щорічник «Актуальні проблеми нефрології» (Свід. про реєстрацію друкованого засобу масової інформації серія КВ № 7480 від 25.06.03 р.), згідно з Наказом МОН України № 153 від 14.02.14 р., включений до переліку фахових видань, де можуть бути опубліковані матеріали докторських і кандидатських дисертаційних досліджень.

Редколегія доводить до відома авторів, що необхідно дотримуватися наступних вимог.

До щорічника «Актуальні проблеми нефрології» приймаються оригінальні статті та огляди літератури 3 актуальних проблем клінічної, експериментальної нефрології, історії нефрології, ювілейні матеріали, повідомлення про винаходи та корисні моделі, міжнародні і вітчизняні нефрологічні наукові та науково-практичні форуми, лекції, рецензії, некрологи тощо.

Статті прийматимуться на кафедрі пропедевтики внутрішньої медицини № 2 НМУ за адресою:

Головним редактором проф. Валентиною Олексіївною Мойсеєнко, кафедра ПВМ № 2 НМУ, вул. П. Запорожця, 26, корпус 2, I поверх, 02660, м. Київ.

Контактний телефон: +38 067 777-92-49,

E-mail: moyseyenko_vo@ukr.net

Статті українською або англійською мовою обсягом 4-12 сторінок (через 1,5 комп'ютерні інтервали, висота букв - 14) у двох примірниках (на електронному носії) повинні бути придатні для безнабірного копіювання: чорний картридж, без помилок і помарок, стандартні аркуші білого паперу $(210 \times 297$ мм), поля (в см) зліва і справа $-3,00$, зверху і знизу - 2,5. На другому примірнику - прізвища, імена, по батькові (повністю) та підписи всіх авторів, інформована згода (підписана першим автором) на перевірку тексту антиплагіатною комісією, поштова адреса для листування та контактний телефон, e-mail основного автора. Прізвище, ім'я, по батькові (повністю) першого автора (або того, кому доручить група авторів), контактний телефон і (або) e-mail - будуть зазначені в кінці статті - для контактування автора та читача. Необхідно додати флешку 3 набраним (y Microsoft Word) текстом і рефератом статті.

\section{ОБОВ'ЯЗКОВО ДОТРИМУВАТИСЯ ТАКОЇ СХЕМИ:}

$$
\begin{gathered}
\text { УДК } \\
\text { Назва статті } \\
\text { Ініціали та прізвища авторів } \\
\text { Кафедра (відділ, лабораторія), установа, } \\
\text { місто (малі букви) }
\end{gathered}
$$

Реферат українською (англійською, якщо робота англомовна), структурований так, як у статті.

Ключові слова.
Текст статті з такими рубриками: вступ, мета, матеріал і методи, результати та їх обговорення, висновки; текст може ілюструватися таблицями (компактними, тільки у книжковому варіанті), чорно-білими рисунками, схемами, діаграмами тощо, поданими після згадки про них у тексті статті; посилання на авторів [у квадратних дужках - їх порядковий номер у списку літератури].

Скорочення, використані в тексті чи ілюстративному матеріалі, потрібно розшифрувати при першому їх згадуванні. Результати досліджень мають бути виражені в Міжнародній системі (SI), терміни - уніфіковані з урахуванням Міжнародної анатомічної та гістологічної номенклатури, Міжнародної біологічної номенклатури, Міжнародної класифікації хвороб 10-го перегляду, Державної Фармакопеї (X, XI).

ЛІТЕРАТУРА: в алфавітному порядку мовою оригіналу спочатку дається повна бібліографічна характеристика робіт, публікованих кирилицею, потім - латиницею; дотримуватися чинних вимог до подання бібліографічних джерел (Національний стандарт України ГОСТ 7.1: 2006 та 7.80:2007). Посилатися точно і переважно на роботи останніх 5 років.

Обов'язково додаються структуровані (такі самі рубрики, як в основному тексті) резюме статті,а також ключові слова російською (українською) та англійською мовами:

\section{PEЗЮME (SUMMARY) \\ HA3BA \\ Прізвища та ініціали авторів

$$
\text { (Місто) }
$$

Текст резюме - до 250 слів.

На типографські витрати одночасно потрібно внести кошти з розрахунку 100 грн. за кожну сторінку (у т.ч. неповну) статті.

Роботи, які не пройдуть антиплагіатний контроль; за висновком внутрішніх та зовнішніх рецензентів не відповідатимуть зазначеним вимогам; не матимуть належного наукового рівня або написані неграмотно, не зможуть бути включені до збірника.

Для уточнення тиражу просимо авторів, а також головних нефрологів усіх рівнів попередньо замовити у редакційній колегії бажану кількість примірників щорічника для Вас і нефрологів регіону (орієнтовна вартість 1 примірника - 100 грн.).

РЕДАКЦІЙНА КОЛЕГІЯ 


\section{SUMMARY}

\section{THIS ISSUE IS DEDICATED TO THE BRIGHT MEMORY OF THE AN HONOURED FIGURE OF SCIENCE, NYKULA TARAS}

In the following mind readers this Edition 26-27 of the annual year-book "ACTUAL PROBLEMS OF NEPHROLOGY" (the collection of scientific works of National O. Bohomolets Medical University, Kyiv, 2020), edited by honoured scientist and technician of Ukraine, professor, V.O. Moyseyenko, there were included the following materials.

In this annual collection of scientific works published nephrologic review and original articles on Clinical Nephrology copyright creative collectives of Bogomolets National Medical University (Kyiv), SU"Institute of Nephrology of National Academy of Medical Sciences of Ukraine (Kyiv), KNE Communal non-profit enterprise "Kyiv City Center for Nephrology and Dialysis», materials with kidney disease, the information about, a scientific and practical conferences of the State University "Institute of Nephrology of the National Academy of Medical Sciences of Ukraine" with the support of the Ukrainian Association of Nephrologists and Renal Transplant Specialists and the National Renal Fund of Ukraine, World Kidney Day-2020), requirements for articles, which contain materials of the doctor's and candidate's theses on the actual problems of Nephrology.

The revew of newest literatures on changes in kidneys and other bodies. There also is information for authors of this nephrological year-book, alphabetical author index (Ukr. and Engl.). 


\title{
АКТУАЛЬНІ ПРОБЛЕМИ НЕФРОЛОГІї
}

\author{
ЗБІРНИК НАУКОВИХ ПРАЦЬ \\ Випуск 26-27
}

За ред. А.м.н., проф. В.О. Мойсеєнко

Підписано до друку 22.12.2020 р. Формат $60 \times 84 / 8$.

Ум. друк. арк. 9,25. Наклад 500. Зам. 0221220.

Комп'ютерний набір. Друк офсетний.

Зверстано і надруковано в ТОВ "Видавництво "Юстон"

01034, м. Київ, пр. Перемоги, 62-Б, оф. 2 тел.: (044) 360-22-66, www.yuston.com.ua

Свідоцтво про внесення суб'єкта видавничої справи до державного реєстру видавців, виготовлювачів і розповсюджувачів видавничої продукції серія ДК № 4973 від 09.09.2015 р. 